\title{
POLICY ISSUES AND ECONOMIC EFFECTS OF PUBLIC AIDS TO DOMESTIC TRANSPORT
}

\author{
James C. Nelson*
}

\section{I}

The Current Issues over Public Aids in Domestic Transport

In the United States, government shares with private enterprise the risks and costs of providing transport supply in a mixed system of public and private enterprise. In general, although a variety of promotional devices have been used, government furnishes the basic ways (and terminals in some cases), while private carriers supply the equipment, organization, and working capital essential to carrier operations over public facilities. This mixed enterprise is characteristic of air, highway, and water transport, but not of pipeline and railway transport, fields in which private enterprise accepts the responsibility of providing both way and carrier facilities. As most countries operate their railways under public enterprise, this country's particular mix of private and public enterprise in transport is unique.

As a broad generalization, one that subsequently must be qualified in important respects, it can be said that the American system of mixed enterprise in transport (with its relatively heavy emphasis on private enterprise) has worked tolerably well. It has produced a fully-developed, large-scale, multi-service, and essentially competitive transport system that appears the envy of most countries. However, Europeans often question whether automobiles and expressways can ever, by themselves, provide a solution for urban congestion, and observers from underdeveloped countries wonder how a country can afford the large amount of route and agency duplication involved in the American transport system.

Nevertheless, the American policy of directly providing basic facilities, such as airways and inland waterways, and of financially aiding the states to furnish airport and highway facilities has not escaped severe and widespread internal criticism. Today, almost no one questions the desirability of public spending for the airways, airports, highways, and waterways. But increasingly the question has been raised whether it is economically desirable to furnish any of the carrier groups with the ways and terminals they require entirely free of charge, as in the case of inland waterways, or at user charges that may be inadequate to cover all relevant resource

- A.B. I930, University of Washington; A.M. 193I, Ohio State University; Ph.D. I934, University of Virginia. Professor of Economics, Washington State University. Research Fellow, Brookings Institution, 1933-34; Senior Transportation Economist, Bureau of Agricultural Economics, United States Department of Agriculture, 1938-40; Principal Economist, National Resources Planning Board, 1940-4I; Assistant Director, Division of Economic Studies, Board of Investment and Research, I941-44; Chief, Transportation Division, United States Department of Commerce, I945-47; Senior Staff Member, Brookings.Institution, 1956-57. Authơ, Railroad Transportation and Public, Policy (1959). Contributor to economics publications. 
costs involved in rendering way or terminal services to carriers. Stated more pointedly, the critical questions are: Is there a continuing economic justification for the grant of subsidies to certain or all of the classes of carriers that depend on public transport facilities? Is it now feasible to have the full economic advantages that the American mixed system of transport can yield, while assessing appropriate user charges against all carriers using public way and terminal facilities? If the differential grant of subsidies is continued along with other questionable policies, what will be the ultimate social costs in terms of loss of essential and efficient transport plant not receiving the benefit of public subsidy? Specifically, is the deteriorating condition of the privately-owned railroads during a long period of postwar prosperity attributable to any important extent to the direct and indirect subsidies given the expanding transport agencies that rely on public facilities as essential plant for their vehicular operations?

These issues are not new in American transport. But as the aggregate volumes of annual public investment in airway, airport, highway, and waterway facilities have been expanding rapidly, while railway investment has lagged, they have become more urgent, and the day has drawn closer when reasonable solutions must be found. Rightly or wrongly, many observers have arrived at the conclusion that a connection exists between the rising levels of public expenditures for alternative transport facilities (including the generous terms quoted to carriers for their use) and the high and rising level of rail freight rates, the recurring shortages of freight cars, the decisions of prominent eastern railroads to disinvest in basic line capacity, the rising passenger deficits, and the worrisome discontinuance of commutation train services. ${ }^{1}$ At any rate, the enactment of the Transportation Act of $195^{2}$ was concrete evidence of the growing public concern over the long-term consequences of the declining position of the railroads. It also reflects the underlying issue whether railway decline represents ordinary technological substitution bringing superior service, lower costs, and more adequate transport supply for the needs of commerce as a whole, or whether it represents an uneconomic consequence of overexpanded government investment in transport facilities, subsidies to some competing agencies but not to others, and regu-

\footnotetext{
1 The concentration of this article on the problem of transport subsidies should not be construed to imply that it is the writer's view that the long-term and postwar relative decline of the railroads is wholly or even principally due to the effects of subsidies to air, highway, and water transport. Of course, other reasons exist for much of the huge traffic diversions from the railroads in recent years, such as the long-standing inadequacies of rail pricing in relation to rail unit costs and competitive conditions, the restrictive effect of regulation on competitive rate making, superior service by air and motor carriers, and lower unit costs (even with governiment subsidies figured in) for some hauls and services. For a full statement of the basic elements in railway decline, see James C. Nelson, Railroad Transportation and Public Policy (I959). Cf. John R. Meyer, Merton J. Peck, John Stenason, \& Charles Zwick, Thut Economics of Competition in the Transportation Industries 65-85, 122-26, 139-44, I48, 166.96, $238-52,265-69$ (I959).

${ }^{3} 72$ Stat. 568, 49 U.S.C.A. $\$ \$ 1231-40$ (Supp. 1958). See also Senate Comm. on Interstate and Foreign Commerce, Transportation Act of 1958, S. REP. No. 1647, 85th Cong., 2d Sess. (1958); House Comm. on Interstate and Foreign Commerce, Transportation Act of 1958, H.R. REP. No. 1922, 85th Cong., $2 d$ Sess. (1958). S. Res. 303, 85th Cong., 2d Sess., 104 Cong. Rec. 8370 (1958), authorized the Senate Interstate and Forcign Commerce Committce to investigate a number of transport policy questions, including public aids and user charges for public transport facilities.
} 
latory policies preventing or slowing the market and price adjustments of the railroads to the growing competition which they face (and which is in prospect) from alternative agencies differentially enjoying the benefits of government provision of their ways and/or terminal facilities.

The problem of subsidies in transport is far too vast and complicated for full statistical treatment in this article. This discussion is limited to viewing the subject in general terms in the light of present-day conditions, rather than to presenting a complete historical and quantitative account, such as was done two decades or so. ago by the Federal Coordinator of Transportation and the Board of Investigation and Research. ${ }^{3}$ Special attention will be given to ascertaining whether it makes economic sense to continue traditional areas of subsidy to some transport agencies more or less indefinitely, and whether it is now feasible for the federal government to adopt a policy of universal user fees. Throughout, the long-term economics of the subject will be stressed, rather than the acquisitive, regional, or income-distributional effects of subsidies. The basic assumption made is that the objective of national transport policy, to be economic, must be to encourage the development of a transport system capable of minimizing the total costs in scarce resources required for producing continuously and adequately the mix of transport services demanded at prices that are closely related to the costs of supplying those services. Hence, public aids will be discussed in terms of their contribution or lack of contribution to that over-all objective.

\section{The Historical Policy of Public Aids to Transport}

With the exception of the pipelines, all domestic transport agencies and the American shipping lines and airlines in international commerce have received subsidies from government at some time during their development. It will, therefore, be instructive to note the kinds of aids granted, the purposes established for them, the conditions attached, and the resulting social gains achieved.

During the nineteenth century, certain western and southern railroads were beneficiaries of federal land grants (and of other state and federal aids), extended to encourage initial construction of rail lines into areas without efficient transport service and into virgin western regions; in return, the land-grant railroads were obligated to quote land-grant rate reductions for transportation of mail, troops, and govern-

${ }^{3}$ Sce Federal Coordinator of Transportation, Public alds to Transportation (1938-40); Board of Investigation and Research, Public Aids to Domestic Transportation, H.R. Doc. No. 159, 79th Cong., Ist Sess. (1945); Board of Investigation and Research, A Report on Carrier Taxation, H.R. Doc. No. 160, 79th Cong., Ist Sess. (1945). The terms "subsidy" and "public aid" are used interchangeably to mean both the grant of money and the provision of facilities or services by government without requiring fully compensatory payments. Public expenditures for transport facilities do not necessarily result in public aids or subsidies; they do, however, to the extent that uncompensated costs result from a complete lack of user fees, from iniadequate user charges, or from grants of money or land that are not repayable. See Board of Investigation and Research, Public Aids to Domestic Transportation, H.R. Doc. No. 159, 79th Cong., Ist Sess. 52-55 (1945). 
ment property (an obligation that continued until October I, I946). Earlier, canals had been constructed by state agencies and furnished to water carriers at tolls designed to recover capital and operating costs; however, since about 1880 , by which time the railroads had largely superseded the canals, the federal and state governments have provided improved waterways to the barge lines entirely free of user charges, except on the recently completed St. Lawrence Seaway, an international facility. Even earlier, private turnpikes supplied improved main highways on a commercial basis; but since the decline of turnpikes after 1850 , the provision of highways has been the responsibility of the state and local governments, with the federal government granting ever-increasing aid (since rgr6) for construction of limited. federal-aid systems of state, municipal, and county highways. ${ }^{5}$ However, almost from the beginning of the modern highway movement around the turn of this century, motor vehicle owners have been assessed user fees (registration fees at first, and then motor fuel and other special taxes) for use of the public highways. Finally, the federal government undertook to provide the civil airways in the early days of air transport, and even today furnishes the airways to aircraft operators without explicit user fees (although an excise tax of two cents a gallon on aviation gasoline is paid to the federal government). And for many years, federal air-mail subsidies have been awarded to the domestic and international airlines, although they no longer are given to the domestic trunk lines which carry a very large proportion of the traffic. In addition, local government, with federal aid, furnishes essential airport facilities, assessing the airlines user charges that, however, have not been sufficient, along with other sources of airport revenues, to make public airports self-supporting enterprises. ${ }^{6}$

Over the years, tremendous sums have been spent by government in making way and terminal facilities available for use by private carriers, in giving direct subsidies to certain classes of carriers, and in engaging in expensive scientific research and development for national security-one result of which has been that much valuable technology has become available to the air carriers without their having to finance other than the cost of its adaptation to civil aviation. ${ }^{7}$

In a study recently published by the Brookings Institution, the present writer estimated that the aggregate federal spending (of which only a part represented subsidies) for air, highway, and water facilities and services (not adjusted for changes

\footnotetext{
- For a brief review of state and federal aids to the railroads, including federal land grants during 1850-71, see D. Philip Locklin, Economics of Transportation roo-I9 (1954); Heniry, The Railroad Land Grant Legend in American History" Texts, 32 Miss. VAL. Hist. REv. 171 (1945). The reduced-rate obligation continued until it was repealed by the Congress in 1946; by that action, the Congress recognized that more than full compensation had been made for the federal grants of land to certain railroads. The total of all land-grant rate reductions (including voluntary equalization of rates by competing roads) to June 30, 1943 , was estimated to be $\$ 580,000,000$, a sum several times the value of the granted land at the time land grants were awarded and in excess of the sums derived by the railroads from the grants.

LockLIN, op. cit. supra note 4 , at $75-87,750-68$.

${ }^{6}$ NeIson, op. cit. supra note 1 , at 93-107.

' Statement of Burton N. Bëhling, in Railroad Paśsenger Train Deficit, No. 31954, ICC, Feb. 18, 1958, pp. 7-16.
} 
in the value of the dollar) amounted to $\$ 43,000,000,000$ through fiscal $195^{8}$. That total included the $\$ 16,900,000,000$ of expenditures for the merchant marine for emergency ship construction during two world wars and for mail or construction and operating differential subsidies. Without that component for international shipping facilities and services, total federal expenditures for domestic transport facilities amounted to $\$ 26,100,000,000$ through fiscal $195^{8}$. Of that total, the greatest amount, $\$ 17,500,000,000$, went for highway development; the second largest amount, $\$ 5,400$, 000,000 , for inland waterway development (excluding $\$ 95,700,000$ expended for the St. Lawrence Seaway); and the third largest amount, $\$ 3,200,000,000$, for civil airways and airports and for mail subsidies to air carriers. ${ }^{3}$ In addition, expenditures for highways by state and local governments in recent decades have greatly exceeded the total federal aid for highways, and probably even the aggregate federal expenditures for all types of civil transport facilities. In contrast, total federal grants to the rail roads, in large part the value of granted land, amounted to only $\$ 1,400,000,000 .{ }^{9}$

The national purposes for giving financial assistance in behalf of transport development are relevant in any evaluation of that policy. Clearly, grants to the railroads had the somewhat unique national objective of initially stimulating settlement and use of the undeveloped lands in the West by means of rapid introduction of a new transport technique capable of substantially reducing the cost of longdistance transport and of improving the speed of service. On the other hand, most merchant-marine expenditures have been for the purpose of increasing the supply of ships for military needs during World Wars I and II and of maintaining, during peace periods, sufficient merchant ships, shipbuilding and repair facilities, and trained personnel for any military eventualities that might arise. Aids to air transport sought to improve postal communication and to hasten the introduction of a new means of transport capable of unique speeds of service, as well as to assure adequate equipment, aircraft-manufacturing facilities, and skilled personnel for national defense. Federal aid to highways had as its principal purposes the improvement of rural postal services and the promotion of interstate commerce through stimulating competitive transport; in addition, there has always been an underlying national defense interest in a highly developed system of interstate highways based on the needs of commerce and, therefore, generally adequate for the needs of the military in time of war. State and local investment in modern highways has largely been in response to the way-service demands of a rapidly multiplying ownership of motor vehicles, as the willingness of user groups to pay user fees and a growing proportion of total highway costs attests. The principal objectives for federal channelization of the inland waterways, including the no-toll policy, have been to give some landlocked areas

${ }^{8}$ NeLson, op. cit. supra note 1 , at 67-7I. It is recognized that price levels have changed and that population and traffic have grown during the century since the land grants were awarded certain railroads to encourage construction. It is also recognized that comparison of the ratios of public expenditures and grants for transport facilities to gross national product at different historical periods might be pertinent.

- Charles L. Dearing \& Wirfred Ofen, National Transportation Policy iI (i949). 
(principally the Mississippi Valley) lower freight rates than the railroads would otherwise have quoted (even under ICC regulation) and to furnish additional competition against the pre-I930 monopoly power of the railroads; and as in the case of the other agencies, there was also some military interest in having these supplementary facilities in time of war. ${ }^{10}$

Except in the special case of the merchant marine, the over-all historical record indicates that perhaps the strongest motive for federal transport subsidies has been to bring about more rapidly than otherwise would occur the economic and social benefits of improvements in transport service and lowered transport costs when entirely new transport technology became available. This was true of federal aids for highway and air-transport development. That objective was also a prominent reason for the land grants to certain railroads decades ago, but with the significant difference that a century ago far greater emphasis was necessarily placed on land settlement and general economic development of the vast resources of pioneering areas. The introduction and rapid expansion of modern air, highway, and waterway transport came after a complete and efficient railway system had been established by private capital, with some reimbursable aid (land-grant rate reductions) from the government, and long after the railroads had already opened up most of the remote and undeveloped regions of this country for rapid settlement and population growth. It follows that the public aids given to the newer forms of transport have largely been premised on improving transport with service innovations and through promoting additional competition. This is not to say that public promotion of airways and airports, highways, and waterways did not somewhat expand the extensive margins of land use nor contribute to national economic growth. It rather implies that the basic problem has long ago changed from the establishment for the first time of a superior means of transport over wide areas in order to promote general economic development, to the problem of assisting in the introduction of new modes of transport as they appeared on the scene, with the purpose of refining the existing well-developed system with new services, coordinated transport, and in some traffic areas with less costly service in terms of resource costs. In other words, the grant of subsidies to air, highway, and waterway transport was intended to speed the development of those modes over the normal rate which market demand would in time have stimulated, in order that the economy might earlier enjoy the benefits of new types of services, new technologies of transport, and competitive transport organization.

According to some authorities, federal transport promotion has achieved good long-term results on the whole. ${ }^{11}$ Thus, grants to the railroads stimulated a rapid spatial development in the nineteenth century by encouraging efficient regional specialization on the basis of reductions in transport costs and improvements in serv-

${ }^{10} \mathrm{Id}$. at $12,8 \mathrm{I}-94,236-65$. It should be pointed out that students of transport have long recognized that subsidized waterways cannot be an effective regulator of railroad rates generally; and that while such "free" improvements confer advantages on some otherwise landlocked areas, they discriminate against landlocked areas which have no access to waterways, actual or potential.

${ }^{21}$ Id. at $12-13$. 
ice much earlier than would otherwise have occurred. Federal aid to highways fostered a rapid and high development of the principal interstate highway routes (along with a large mileage of highways of lesser significance in recent years); it also induced early adoption of scientific highway management and planned highway development. Although the contribution of motor transport to the economy is harder to evaluate than that of the railroads, the steady emergence of competitive transport markets after about 1920 is one of the most noteworthy contributions of motor transport and modern highways. Air transport, whose amazing growth has clearly been expedited by the pioneering government operation of the original airlines, ${ }^{12}$ government provision of airways and airports, the grant of air-mail subsidies, and by strong federal regulation of airline safety standards, has also added competitive elements in transport. However, air transport's chief contribution has been its tremendous speed of service, benefiting postal communication, travel, and the shipment of high-grade commodities alike. This century's waterway development has added additional competitive elements and has given the particular areas favored with waterways a low-priced but subsidized service for bulk and special commodities.

Both the subsidies to the merchant marine and those given to commercial air transport have contributed importantly to the supply of facilities, equipment, and trained personnel that have been critically needed in recent wars. However, although national defense needs may justify continuing subsidies to maintain a merchant marine larger than the commercial market would supply, it cannot be overlooked that without such subsidies, the privately-owned railroads and pipelines (including the government-constructed Big Inch and Little Big Inch lines, now in private ownership) also made highly significant contributions to essential transport supply during World War II. The intercity highway carriers played a lesser but important role in the war effort, even though they had long been required by the states to make substantial user fee contributions in support of the public facilities over which their vehicles operate. Accordingly, a significant conclusion to be drawn from history is that when domestic transport agencies have been in adequate supply for the normal needs of commerce, their capacity has also generally been sufficient for wartime and defense needs, although some special coordination and rationing in terms of wartime essentiality criteria and some minor adjustments in supply to accommodate special defense needs have been required. The contribution of the domestic transport industries to wartime economies indicates that, aside from the case for subsidies to encourage the initial development of brand new modes of transport, or for action to overcome an unbalanced development of transport facilities due to the effects of public policies, there is no need for continuing subsidies to any domestic field of transport in order to have adequate facilities for military needs. ${ }^{13}$

${ }^{29}$ Joseph L. Nicholson, Air Transportation Management 7-r 8 (i95I).

${ }^{13}$ Cf. Harbeson, Transportation: Achilles Heel of National Security, 74 PoL. Scr. Q. I (I959). 
Beyond question, then, government has made a truly important contribution to development of the superb and highly-refined American transport system. But as government promotion has also created excessive transport facilities and economic distortions, this by no means implies that all is well or that the best and most efficient system has resulted from the combined efforts of government and private enterprise. Nor does it logically mean that the policies of the past should be continued indefinitely without change. However, continuing subsidies may be essential to assure a sufficient and modernized supply of overseas shipping facilities.

When one looks objectively at the problem of the justification for subsidies to domestic transport, it is clear that all of the historical reasons, excepting political and pressure-group demands, have disappeared long ago in most cases. Clearly, there is no present need for land grants or equivalent aid to stimulate an initial development of a rail system, although a serious lag in rail investment in terms of modernization and additional equipment has long been cause for public concern. Highway motor transport is now a mature and thriving industry, and principal highway routes with high-type surfaces have been established throughout the land. Although expanding traffic and congestion in and near cities obviously require much highway expansion and modernization, plainly there is no longer any need for public subsidies from general tax funds in order to introduce the advantages of this technique of transport to the American economy. Very likely, most economically-needed highway development would come as rapidly as can be justified, considered competing needs for scarce resources and consumers' preferences for all goods and services, on the basis of effective demand, if user fees and tolls were adjusted appropriately and if the principle of user support of highways were applied more fully and insistently. The quick additions to expensive and superior highway supply in congested areas by the state-owned toll road authorities appear to indicate that the required facilities would come sooner on that commercial basis of organization than under the existing so-called free-road policies.

Air transport, too, can no longer be regarded as an infant industry in need of continuing subsidies to assure its development, except for the somewhat noneconomic case that has been made for subsidizing the local and metropolitan airlines to give rural areas and urban communities more of the advantages of the air age. It is noteworthy that the rapid introduction of new technology in air transport did not cease, or even slacken, nor did rapid growth stop, with cessation of air-mail subsidies to the significant trunk lines. Witness the $195^{8-59}$ introduction of pure jet transports. Despite a natural disinclination by the airlines to make adjustments to increased costs when a way can be found to avoid them, it is doubtful that placing explicit and adequate user fees on the civil airways over a period of time would seriously impede beneficial innovations in that industry. The great growth of the traffic of barge lines serving ports on the well-located inland waterways would seem to indicate that free channel and lock services are no longer essential to intensive use of such facilities. In the case of marginal waterways, the traffic does not develop 
to high levels even without user fees, a situation that has raised serious questions about the economic justification made for some waterways and the legislative decisions to invest in them.

Manifestly, the conditions that originally prompted adoption of the particular subsidy and promotional policies chosen in the pioneering phase of this country's development and during the early years of the development of each of the transport industries (except the pipelines) no longer obtain. This does not mean that government should withdraw altogether from promotion of transport agencies; rather it should comprehensively review its historic promotional policies in order to bring them in line with the present-day needs of commerce, the postal service, and national defense. Obviously, there is no reason to withdraw from government ownership and investment in airways, airports, highways, and inland waterways, as these are all widely-accepted governmental business functions. However, the greatly changed conditions in transport since the original subsidy policies were initiated, the urgent need for achieving greater over-all economy in transport, and the many competing claims for general tax revenues at both federal and state levels logically argue for the total elimination of subsidies to so-called infant transport industries that clearly have developed into market and traffic adulthood and have been competing vigorously and successfully with the privately-owned agencies not enjoying continuing and equalizing subsidies but, in contrast, having to bear both the overhead costs of way investments and a full load of taxes on their way facilities.

\section{III}

\section{The Effects of Public Aids upon the Current Transport Situation}

The beneficial general results of this country's policy of stimulating economic development through encouraging adequate and efficient transport and by fostering technical innovation and competition in transport refer to a long-term historical period during which all of our modern transport agencies have evolved from the stage of experimentation and infancy into mature industries. Those gains, along with tremendous economic wastes from overdeveloped facilities on many routes and from encouragement of traffic flows over high-cost agencies, ${ }^{14}$ have long ago been achieved. Today, the problem of transport policy is radically different than in the 1830-r930 period. Insufficient attention has been given to this fact in formulating promotional and regulatory policies in recent years.

The transport problem today and in the foreseeable future is to promote the right economic development of each of the five contending agencies, including that of the several classes of carriers and of coordinated services by two or more classes of carriers. No longer can the primary aim of policy be to foster initial economic development of the western regions through establishing effective transport supply

\footnotetext{
16 Dearing \& OWen, op. cit. supra note 9, at $\mathrm{I}_{3}-\mathrm{I}_{5}$; Merton $\mathrm{H}$. Miller, Price Discrimination in the Railway Industry, 1952 (unpublished Ph.D. dissertation in Johns Hopkins University Library); MEYER, PecK, Stenason, \& Zwick, op. cit. supra note I, chs. VI and VII.
} 
(except for the new state of Alaska ${ }^{15}$ ), or even to hasten the introduction of new transport industries by means of temporary or continuing subsidies. This is not to say that modes of transport now not visualized will never be invented nor appear on the market horizon. Considering the dynamics of the space age, it is conceivable that new transport methods, superior to existing ones, are now in the making. However, the present-day policy-makers, and, indeed, the entire citizenry, currently face well-defined and critical transport questions growing out of the existing relations among agencies and carriers, the current promotional and regulatory policies, and the present structure of transport. Thus, it would seem wholly reasonable to give priority to such issues, leaving the question of what subsidies may be desirable for promoting rapid development of any new mode of transport to be dealt with after someone invents it and it has actually appeared on the scene in tangible form.

The most critical issue in transport today involves what to do about the deteriorating postwar condition of the railroads and the multiplying evidence of long-term railway decline. If the newer agencies, air, highway, pipeline, and barge transport, are truly superior to the railroads in service and in resource costs, and if, all traffic needs considered, those modes can completely and efficiently take the place of the railroads, then the problem would be a simple one of determining the proper rates of disinvestment in railway facilities and of abandonment of rail services, while investing sufficiently in other transport to carry the traffic load from which the railroads would progressively be released. Even so, there would be no economic reason for subsidizing any of the newer agencies, except in the very early stages of initial development. On the other hand, if the new agencies cannot substitute completely or sufficiently for the railroads and cannot give as comprehensive or as lowcost service as the rail carriers, then the problem is far more difficult, and wholesale revision of past policies in transport will be essential.

At this point, a résumé of the well-known facts revealing a long-term decline in the market position of the railroads is pertinent. The principal facts are as follows:

I. The railroads' postwar freight traffic has averaged about forty per cent above the 1926 and 1929 levels, representative years during the last sustained prosperity era previous to the present one.

2. Notwithstanding, the rail share of total intercity ton-miles has dropped from seventy-five per cent or more to 46.3 per cent in 1957 , while the shares of the truck lines, barge lines, and pipelines have all risen greatly.

3. Rail ton-miles have not exceeded the 1947 postwar peak in subsequent years, whereas total intercity ton-miles have risen by a third and the combined intercity volume carried by competing truckers, barge operators, and pipelines has doubled since that time.

\footnotetext{
${ }^{25}$ See Alaska Internationat Rail and Highway Commission, Additional Transportation Facitities to Alaska (I959); Sumarary of Previous Studies (I957).
} 
4. After a phenomenal wartime increase in rail passenger-miles, the passenger traffic of the railroads has fallen steadily, the 1956 volume being only about fourfifths as high as the r $926-29$ level and the rail share being only 4.09 per cent of total intercity passenger-miles by all agencies in that year (3.65 per cent in 1957), compared with twenty-two per cent in 1926.

5. In many transport markets, including those of medium hauls, where much traffic is concentrated, the railroads have lost so much of the high-rated, profitable types of traffic that frequently their market shares of specific items of manufactured and miscellaneous traffic between particular points have been reduced to negligible percentages, and even to zero in not a few cases.

In brief, while the trucks increased their intercity traffic by more than $150,000,000$,ooo ton-miles since r947, the pipelines added more than 125,000,000,000 ton-miles to their total, and the barge lines added about $80,000,000,000$ ton-miles to their volume, the railroads stood still in freight traffic; and much of the most profitable types of traffic, even transcontinental hauls, shifted away from them. Obviously, the railroads did not participate in the growth of the postwar economy, while their principal freight competitors attracted an additional volume in excess of one-half the annual freight traffic of the railroads in postwar years. Much of the passenger traffic lost by the railroads shifted to the airlines. In addition, the private automobiles took away most of the vast new intercity travel during postwar years, with the airlines commanding a small share. ${ }^{16}$

The revenue, profits, and capital-investment effects of those huge shifts of traffic from the railroads have been disastrous, except in the case of certain southern and western roads that enjoyed traffic gains from population and industrial growth and except for the highly unique Pocahontas coal railroads. Although accounting for the total revenues or revenue equivalents (operating expenses) of all agencies poses problems, it is clear from the available data that the aggregate revenues of all carriers, including the revenue equivalents of private carriers, have risen during postwar years as a result of two forces: inflation and traffic growth. Rail revenues, like those of other agencies, have expanded, but the postwar growth of rail revenues has not kept up with that of competing agencies. The reasons for these contrasting trends are that the accretions in rail revenues represent inflation in freight rates only, whereas the revenue gains of competing agencies represent both higher freight rates and far larger traffic volumes.

The rail share of the estimated operating revenues of all carriers subject to federal regulation dropped from 72.I per cent in 1947 to fifty-six per cent in 1956 (total revenues expanded from $\$ 13,100,000,000$ in 1947 to $\$ 20,300,000,000$ in 1956 , while those of the railroads rose only from $\$ 9,500,000,000$ to $\$ 1 x, 400,000,000)$. While the total freight revenues of motor carriers (including the revenue equivalents of private carriers and of the for-hire groups for which revenues are not reported) rose from

${ }^{10}$ NELSON, op. cit. supra note I, chs. 2,3 . 
an estimated level of $\$ 1,700,000,000$ in 1940 to $\$ 13,600,000,000$ in 1955 , rail freight revenues increased only from $\$ 3,500,000,000$ to $\$ 8,500,000,000$. Hence, the rail share of combined motor-rail freight revenues dropped from 67.4 per cent to 38.7 per cent. Finally, domestic scheduled airline revenues rose from $\$ 55,900,000$ in 1939 to $\$ 1,201,100,000$ in 1955 ; in the same period, rail passenger revenues increased only from $\$ 417,700,000$ to $\$ 743,700,000$, or by less than a third of the airline gain. ${ }^{17}$

As might be expected from the traffic and revenue trends cited, the railroads have been a low-return, "sick" industry during the postwar era. In the same period, the motor carriers, barge lines, pipelines, and airlines have generally prospered in terms of rising aggregate net profits and relatively attractive rates of return on net investment. Direct and indirect subsidies to some of those carriers no doubt contributed to this result. The evidence of the railroads' financial distress, in the form of low and uneven earnings, is so well known that it need not be presented in detail here. However, for more than a decade, the rail industry's rates of return on net investment, with few exceptions, have been at the three to four per cent level, and the profit situation has been far worse for the Eastern District railroads, where some of the nation's largest and most important roads, such as the Pennsylvania and New York Central, operate. As the record of operating deficits during the $1957-5^{8}$ recession revealed, such low levels of returns are insufficient for important railroads to establish sufficient reserves to tide them over adverse times without experiencing the threat of bankruptcy. Rail passenger traffic has declined so seriously that railroads carrying passenger traffic have experienced huge full-cost passenger service deficits (up to $\$ 724,000,000$ a year in 1957), and even large and rising deficits (up to $\$ 121,000,000$ or more a year) when passenger train revenues are measured against the solely related expenses, taxes, and rents attributable to the passenger service, according to ICC accounting standards. To a considerable but not precisely known degree, the passenger-service deficits have contributed to the over-all low profitability of the railroads. An additional fact of material significance is that the low-profit railroads represent more than one-half of the entire industry, rather than a few marginal railroads. ${ }^{18}$

Among general effects that touch the shipping and traveling public are the recurring freight car shortages, the lack of sufficient modern freight cars, the discontinuance of hundreds of branchline and local mainline passenger trains, the threat of eventual loss of many or all commuter trains serving the largest metropolitan centers in the country, the ever-rising freight rates and passenger fares as the railroads have attempted to counter wage and price inflation with higher rates on the same or lower traffic, retarded capital investment in several areas of railway operation, and finally, considerable disinvestment in multiple main-line capacity, especially by the eastern railroads. Excess capacity in basic plant has especially plagued those roads because of the shift of industry to southern and western regions, the rapid highway improvement in the Northeast, and the tremendous growth of truck compe-

\footnotetext{
${ }^{17} 1 d$. at 23-29.
}

18 Id. chs. 7,9 . 
tition in reflection of better highways and the comparatively short distances between major eastern centers. Only recently have these effects commanded widespread public discussion. No doubt, the threat of loss of needed commutation and other rail passenger services has stimulated a general interest in the railroad problem. Such unsatisfactory conditions have again raised the question whether the everexpanding public spending programs and continuing subsidies have discouraged railway progress and increased rail and investor determination to withdraw from unprofitable services.

But not all effects of the current rail situation are disturbing. After too many years of hesitation, the railroads have now been stimulated by competition and adversity to inaugurate a program of vigorous competitive rate-making, to offer new and coordinated services such as hauling trailers on flat cars under several different plans, and to experiment widely with new types of rates and shipper incentives designed both to reduce unit costs and attract traffic. In addition, the roads have been encouraged to find new ways of substituting capital for labor, to modernize motive power and other facilities as rapidly as financially feasible, and to seek solutions to long-standing labor and regulatory problems.

No doubt, many observers will be inclined to argue that if the railroads will attack their competitive, modernization, and efficiency problems with sufficient enterprise, the critical economic situation of the industry will correct itself without any basic change in public policies. Others will contend that the rail difficulties are wholly due to desirable technological substitution, rather than to uneconomic displacement reflecting the differential advantages of subsidies, public way and terminal tax exemption, and not having to bear the overhead costs of investment in ways and terminals. Some will argue that the differential subsidy, tax, and cost-structure advantages afforded air, highway, and water carriers are too minor, in any event, to be found responsible for railway decline and its emerging long-term effects.

These varying views merit careful analysis by all concerned with the transport problem. However, even if the railways have not done all in their power to improve their market position, the correction of such condition would in no way justify continuation of subsidies to other agencies. And although the rail spokesmen may have overemphasized the contribution of public aids and subsidies to railway decline and may have minimized management's role and other factors, a position that differential aids and subsidies have not been a factor in railway decline would be untenable. For one thing, such a position overlooks the fact that the effects of subsidies to competing modes have been cumulative over a long period and probably are becoming greater each year as a result of expanding public expenditure programs and the lag in adoption of user fees. While it is not possible to conclude exactly how much of the rail loss of market and income position has been due to subsidies and to differential advantages from use of public ways and terminals, nor to establish how much of that market loss can be attributed to fully economic technological substitution, the most logical inference seems to be that some material 
loss of rail traffic, revenues, and profitability can be assigned to uneconomic subsidies and to the other special benefits of public aids.

The view sometimes advanced that the trend toward displacement of the railroads is not a serious economic problem rests fundamentally on the obvious fact that the traffic and revenue shifts from the railways have resulted from the choices made by shippers and travelers in markets for transport services after giving consideration to the relative advantages of the alternative services and rates available to them, including the services and costs of private carriers. But the exercise of shipper and traveler choice alone is not sufficient to assure an economic distribution of traffic and allocation of resources in transport. Those results can be assumed to occur through markets only when all resource and social costs involved in supplying each of the several types of transport service are covered in the rates quoted to shippers and travelers (and are included in private carrier costs), and then only when the rates appropriately reflect the cost of the different services rendered. There are other conditions essential to an ideal division of traffic and allocation of resources between transport and other products that need not be detailed here. ${ }^{10}$

Are all resource and social costs of producing alternative transport services included in the rates which shippers and travelers must pay, or in the alternative costs that must be borne if private transport is chosen? Beyond any doubt, the answer must be in the negative. Thus, the barge lines, whether operated for-hirc or as private carriers, do not make any direct payments for their use of government-provided channels, locks, and navigation aids, even to defray such recurring expenses of operation as for labor, electric energy, and maintenance. Considering the comparatively inferior service by water, the cost per ton-mile thereby escaped is sufficient in relation to bargeline carrier costs to allow barge rates to be enough lower than they otherwise would be to attract an unknown amount of traffic from other agencies, principally from the railroads. The less-than-compensatory airport charges and the lack of fees for use of the federal airways also lower the service costs of air carriers below what they otherwise would be. However, with air travel over long distances so superior in speed to surface travel, it is less certain that adding the costs cscaped by the airlines to their fares would materially reduce the volume of long-distance air travel. Undoubtedly, substantial marginal short-distance travel and some aircoach business over longer hauls might go by other agencies if all airway and airport costs reasonably attributable to the airlines were charged and were reflected in air fares; and the volume of air cargo, because costs and rates are now so high as drastically to limit traffic, might be reduced somewhat if all airway and airport costs had to be borne by the airlines.

In the case of the highway carriers, the matter is greatly complicated by the fact that both automobiles and commercial vehicles have long paid user fees and large annual amounts toward sustaining the capital and operating costs of the public

\footnotetext{
${ }^{19}$ Id. at 187-88; J. R. Sargent, British Transport Policy ch. I (1958); Meyer, Peck, Stenason, \& Zwick, op. cit. supra note $\mathrm{I}$, ch. VII.
} 
highway system. There is no part of that system which is furnished entirely free of any charge, as in the case of the inland waterways. One view is that motor vehicles may pay more than the marginal costs of operating the highways, since state and federal user free systems have raised capital funds in large amounts in addition to covering operating and maintenance costs-and in some cases, even total amounts greater than all highway expenditures. According to that view, the marginal costs of motor carriers may have been raised by highway contributions to levels higher than are economic and thus not enough economic diversion from railways to highway carriers has occurred. ${ }^{20}$ On the other hand, it has many times been demonstrated that the largest and heaviest vehicles do not pay fully in proportion to their use of the highway plant, for, with the exception of a few states, the significant diesel-powered trucks and buses do not pay a differential fuel tax to compensate for their higher miles per gallon as compared with gasoline-propelled trucks and buses. In addition, graduated registration fees are usually not adjusted so that the high-mileage vehicles must pay proportionately more than the low-mileage vehicles of the same type, and only a comparatively few states have adopted weightmile taxation. However, it is a matter of controversy whether the large and heavy vehicles pay user charges sufficient to bear the full additional investment and maintenance costs that their size and frequent heavy axle loads make necessary, although a good deal of factual information suggests that they may not in many states. ${ }^{21}$ Hence, while highway users as a class do, in large part, support the public ways they use, there can be no assurance that all subsidies to the truly significant heavy and long-distance highway carriers have been eliminated.

Even though existing user fees may be adequate to cover the annual costs actually occasioned in rendering highway services to automobiles and other light vehicles (and those of other classes of vehicles in some jurisdictions), it cannot be overlooked that there are other special advantages to the users of public way and terminal facilities that are not available to carriers owning and maintaining their own basic plant facilities. These arise from the following facts:

I. State and local property taxes are not levied on airways, airports, highways, and inland waterways, whereas they are levied on the road and track facilities of the railroads and on the pipelines.

2. Capital funds are often available for public investment in ways and terminals at lower interest cost than are funds for investment in private facilities, reflecting the income tax-exempt status of state and local bonds and the added security of the taxing power behind many government bonds.

3. Air, motor, and water carriers are spared the necessity of raising capital funds for construction of public way and terminal facilities, and of bearing the fixed costs attributable to provision of airways, airports, highways, and waterways.

${ }^{20}$ Miller, supra note 14 , at $37 \mathrm{I}-72$.

${ }^{21}$ See references to federal and state highway user-fee studies in Tallamy, First Progress Report of

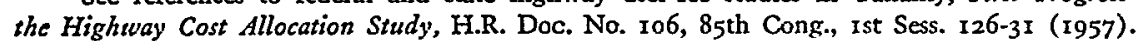


User fees for highways and airports do not include property tax amounts equal to the state and local taxes that would have been levied on those facilities if they had been in private ownership. Estimated property taxes on the line facilities of the railroads amount to more than $\$ 200,000,000$ a year. ${ }^{22}$ If user fees are to make shipper and traveler choice truly effective in selecting the most efficient transport alternative, they should include property tax equivalents with respect to public ways and terminals. $^{23}$

It is true that motor-vehicle owners, including motor carriers, pay general excise taxes to the federal government on motor vehicles and parts. However, since passage of the Highway Revenue Act of $1956,{ }^{24}$ converting a portion of those taxes into federal highway user fees and all federal excise taxes on motor fuels, tires, and tubes into payments for federal-aid highways, the aggregate annual amounts of such general tax contributions have been lessened.5 To ascertain whether the remaining general excise taxes equalize the cost situation as between highway carriers and the railroads would require a comprehensive factual study. ${ }^{26}$ In the case of airways, the twocent excise tax on aviation gasoline (after refunds) cannot be considered both a partial payment toward the annual user costs of airway services, as contended by the airlines, and also a general tax in lieu of property taxes on those public facilities. Inland waterway carriers do not pay federal excise taxes on motor fuels. However, all types of carriers pay applicable property taxes on privately-owned equipment and terminal facilities; and if net income is earned, all privately-owned carriers pay federal income taxes. ${ }^{2 T}$ Notwithstanding, the costs of carriers using public way and terminal facilities do not include all the tax elements of cost with which privatelyowned carriers are assessed recurrently.

Interest on capital funds invested in public transport facilities is included in the costs to be covered by user revenues only to the extent, and at the rates, actually paid. Although tolls for the services of modern toll roads and highway user fees include charges to recover interest actually paid on borrowed funds, it is doubtful that existing user fees for highways and airports have generally included interest at its full social-cost level-that is, at the marginal rate which the capital funds might have earned in alternative private investments. However, in extending public investment in way and terminal facilities, the total costs to be justified by the benefits should include interest on the capital to be employed at the full social costs of government financing, rather than at the lower interest rates at which money can often be

\footnotetext{
${ }^{29}$ Nersos, op. cit. supra note $\mathrm{I}$, at rog. In 1956, Class I railroads paid estimated property taxes on way facilities of $\$ 213,700,000$, or $2 \%$ of the $\$ 10,551,000,000$ of total operating revenues for that year.

${ }^{23}$ Roland N. McKenn, Efficiency in Government Through Systems Analysis 163.65, 205, 242 (1958); Board of Investigation and Research, A Report on Carrier Taxation, H.R. Doc. No. 160, 79th Cong., Ist Sess. 22 (1945).

${ }^{24}$ INT. Rev. CODE of 1954, § 404I et seq. $\quad{ }^{25}$ Tallamy, stspra note 2r, at 27-37.

${ }^{28}$ Such as the report, directed by Dr. Ronald B. Welch, comparing carricr tax payments in 1940 . Board of Investigation and Research, $A$ Report on Carrier Taxation, H.R. Doc. No. 160, 79th Cong., Ist Sess. (1945).

${ }^{27}$ For a summary statement of exemptions and the differential extent of such taxation as of 1940 , sec id. at 2I-50.
} 
borrowed by government agencies or at a zero interest rate if the funds are obtained from taxation. Only when the benefits of a public project are sufficient to cover all costs, including interest at as high a rate as the capital could earn in other employments, can it be assumed that there is greater economy in expanding transport dependent on public facilities than in permitting the traffic to be carried by the privately-owned carriers operating on private ways, enlarging their capacity for that purpose if necessary. ${ }^{28}$ And in the cases in which public way and terminal investment prove to be well-adjusted to the demand for them, economic neutrality would require that the user fees charged for their use should include interest at a rate equal to the full social cost of government financing.

Neither in public investment decisions nor in the pricing of public transport facilities has much consideration been given to the social costs attributable to air and highway transport. On the highways, the additional risks of fatal accidents and the extra time and money costs of congestion and inability to pass on hills are frequent social costs forced on automobile owners by the large trucks and buses. The expanding use of automobiles, for which the streets and parking facilities are grossly inadequate, has been an important factor in making public transit and commutation facilities unprofitable and investment in modernized rapid transit facilities unattractive to private investors. Automobile travel has thus contributed to high-cost and inadequate transit and commutation service for the millions of urban people not owning passenger cars in metropolitan communities where passenger cars cannot physically meet the peak home-to-work travel demands. ${ }^{29}$ But in only a few cases are any of those social costs imposed on the highway users specifically responsible for them. Nor is the social cost of the noise of airplanes fully placed on the airlines and their customers. Of course, the railroads and the transit lines also have created some serious social costs (noise, smoke, and slum dwellings) that the firms and their customers largely escaped in the past, although dieselization of railway motive power has almost eliminated the smoke and soot nuisance of coal-powered steam locomotives. No doubt, the real marginal costs of highway use rise automatically for all motorists and commercial carriers as congestion becomes intense; but this does not necessarily assess the social costs of congestion against the proper classes of motor vehicles, and it does nothing to relieve non-motor-vehicle owners of motor vehicle noise and exhaust fumes nor to compensate them for the deleterious effects of those conditions on health, happiness, and property values.

The points can be made that such social costs are intangible and hard to measure in specific terms, and that in any case, it has not been customary to require private firms and individuals to bear the social costs of their activities along with the money costs priced out to them in the markets for economic goods and the factors of

${ }^{28}$ The opportunity cost of capital for public projects raised by federal taxation was found to be on the order of $5-6 \%$, accepting private time preference, in OtTo Eckstein, Water-Resource DevelopMent 81-104 (1958); and John V. Krutilla \& Otro Eckstein, Multiple Purpose Ruver Development 78127 (1958).

${ }_{20}^{\circ}$ Wilfred OWen, The Metropolitan Transportation Problem I37-4I; 253-54 (1956). 
production. While those points are largely true, this does not mean that social costs should be ignored where such costs are substantial and traceable. It may be noted that both public and private power companies are required to construct and pay the full social costs of installing fishways when power dams are placed across rivers. At all events, where there are uncompensated social costs that may be contributing to the decline of much-needed and economical systems of transport for which complete alternatives do not exist, the problem should be looked into more seriously than in the past. The social disadvantages of rapid expansion of public transport facilities and the attendant encouragement of further diversion of traffic to carriers using public ways from agencies they cannot fully replace should be carefully considered along with the benefits to be derived from that source. At the minimum, uncompensated social costs provide another reason for limiting capital investment in public transport facilities to those amounts and cases for which the economic justification is clear-cut, and for adopting appropriate user fees and tolls for use of all public transport facilities.

As heretofore noted, the carriers using public way and terminal facilities escape the fixed-cost burden of owning their own ways and terminals as well as the necessity of having to raise the capital from private markets for expanding and modernizing those facilities. As a consequence, those carriers can adjust their investment much more closely to changes in traffic demand than can the privately-owned railroads. In addition, carriers using public facilities, especially the motor carriers, are much more flexible in their entry into the best markets for traffic and in their ability to curtail or abandon service as it becomes relatively or absolutely unprofitable. Such advantages, due in large part to organizational arrangements in air, motor, and water transport, could be extended the railroads by government ownership of the rail track facilities, with the privately-owned rail carriers paying user fees for their use. Another solution might be to allow the railroads also to operate airplanes, motor vehicles, and barges over public facilities to the extent such operations may be more profitable than operating trains; but this alternative might mean that some of the advantages of rail operations would be neglected, and, unless controlled according to antitrust law standards, this might again tend to create obnoxious monopoly power in transport.

When consideration is given to the complete lack of user fees in some areas, the questions that can be raised concerning the adequacy of user fees now charged highway and air carriers, the tax exemptions, interest-cost, and investment advantages accruing to carriers dependent on public way and terminal facilities, and the extent to which carrier rates diverge from costs of service, it cannot be concluded that the division-of-traffic trends in transport have been fully economic in the past, even though they have reflected the deliberate choices of shippers and travelers. Thus, it is quite likely that public expenditures and subsidies have influenced more traffic to move by the agencies using public facilities and receiving subsidies than otherwise would have moved over them. Accordingly, the logical possibilities all point to the 
conclusion that subsidies and the differential advantages of public facilities have been factors in long-term railway deterioration and decline.

\section{IV}

\section{The Effect of Public Aids on Capital Formation in Transport}

Transport has long been a field in which technological change and capital investment have contributed greatly to cost reductions and product improvements. Both private and public investment have been important in bringing about rapid transport modernization, once new or improved motive power, carrying equipment, terminal devices, and way facilities had been invented and adapted for actual operations. All factors point to the expectation that capital investment will continue to be tremendously important in transport progress.

But under the conditions that obtain in transport today, can it confidently be expected that the full dynamic technological and modernization possibilities will beachieved in all fields of transport important to the economy? This question has not been accorded the attention it merits in the formulation of public policy, for it has generally been assumed by the policy-makers that the privately-owned agencies, dependent almost wholly on their earnings and the private capital markets for capital funds, can somehow attract the funds needed to develop fully all cost-reducing and service-improving innovations that come along and to supply adequate facilities for the needs of commerce. However, this easy assumption, made by the policy-makers as recently as during enactment of the Federal-Aid Highway Act of $1956,{ }^{30}$ seems not only unwarranted on the basis of current trends in transport, but also likely to lead to tragic consequences if not corrected before long. ${ }^{31}$

Inadequate capital investment is found mainly in the privately-owned sector of transport, particularly in the railway and transit industries. ${ }^{32}$ This is because the appropriation of capital funds for airways, airports, highways, and inland waterways is decided by political processes in both the federal and state areas; because capital funds for those facilities are not entirely limited by the earnings possibilities from their use on the basis of user charges; and because government can, and has, used the taxing power, as well as its superior credit, to raise capital funds for investment in public transport facilities. Not to be overlooked is the influence of widely-held political theories concerning the responsibility of the government for increasing public expenditures, even with deficit financing, to bring about full employment and to counter income-reducing forces in time of recession or depression. To the extent that government investments are expanded for those purposes, public transport programs become eligible for expansion and can be enlarged far beyond the limits imposed by traffic needs and over-all transport economy. A recent example is the ex-

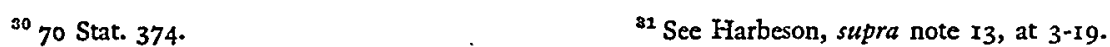

${ }^{32}$ Adequate capital funds have been available for development and modernization of the privatelyowned oil and gas pipelines according to the needs of the market, since those facilities have been integrated with the profitable oil-refining industry, pipeline unit costs have been relatively low, and the volume* of oil and gas traffic has grown rapidly. 
panded rate of federal highway investment authorized by the Federal-Aid Highway Act of $195^{33}$ without raising user fees to pay the additional costs. As already pointed out, the airlines can also count on receiving significant indirect technological benefits from public investments in applied and pure science in behalf of national security. On the other hand, except for the temporary extensions of government credit when the railroads have been in serious financial straits as during the depression (RFC loans) and the $1957-58$ recession (government guarantees of loans, as authorized by the Transportation Act of 1958), and the rapid amortization for tax purposes available to all defense-important industries during recent wars and periods of national emergency, ${ }^{34}$ the privately-owned railroads and pipelines have no comparable political forces bringing about the appropriation of vast capital funds for expansion, replacement, and modernization of their ways and terminals.

Both the vast magnitudes of current public investment in transport facilities in contrast to that in the railroad industry and the rapid expansion of the former as compared with the latter suggest that a real danger exists that insufficient capital may be going into the railways, which still carry almost half of the country's intercity ton-miles and about a third of the intercity travel by common carriers. According to the Bureau of Public Roads, the estimated annual level of capital expenditures by all government units on the federal-aid and other highway systems increased from $\$ 4,997,000,000$ in 1956 to $\$ 7,138,000,000$ in 1959 , or by more than $\$ 2,000,000,000$. Estimated capital expenditures on the Interstate System, the system most competitive with the railways, rose from $\$ 1,282,000,000$ in 1956 to $\$ 2,844,000,000$ in 1959 , or by more than $\$ \mathrm{I}, 500,000,000 .^{35}$ The tremendous increase in annual investment in the key highways was greater than the average annual gross investment, including that in motive power and car equipment, of $\$ I, I 00,000,000$ in the railways during $x 946-55^{36}$ It contrasts greatly with the sharp downturn in railway gross investment in 1958 and I959, reflecting the reduced traffic, revenues, and profits occasioned by the recent recession. ${ }^{37}$

Without raising the logical question whether the huge and rising magnitudes of highway investment portend overinvestment in highways, it takes no prophet to foresee the ultimate outcome of rapid expansion and modernization of highway facilities, while railway investment, particularly in roadway facilities (only $\$ 329,400$,000 per year during 1946-55) lags far behind. This can only mean that railways cannot make the maximum progress of which their technology is capable. It also suggests that the freight car supply will continue to be inadequate and that modernization of freight cars will not occur as quickly as would be desirable. It will take the greatest managerial ingenuity in competitive pricing, in service improvement, and in other

\footnotetext{
s3 72 Stat. 885,23 U.S.C.A. \$§ Ior-3I (Supp. 1958).

34 Nelson, op. cit. supra note 1 , at 20r. Effective Oct. 1, 1959, through June 1961, the federal motor fuels tax was raised from $3 \&$ to $4 \&$ per gallon for highway purposes.

${ }^{35}$ U. S. Bureau of Public Roads, Dep't of Commerce, Release, Estimate of Receipts and Disbursements for Highways, 1956-59, Jan. 16, 1959.

${ }^{33}$ Netson, op. cit. supra note 1 , at 384 . See Railway Age, May 18 , 1959, pp. I6-17.

37 Transport Economics, Dec. 1958, pp. I-2; id., March 1959, pp. 1-2.
} 
areas to compensate for inadequate capital formation by the railroads when investment in public transport facilities constantly expands.

In his recent study of railway capital needs, John W. Barriger has estimated that railroad investment should be doubled-to an average annual level of $\$ 2,000,000,000$ at 1954 prices. $^{38}$ Furthermore, Barriger contends that the greater part of that expanded annual total should go into roadway improvements that would enhance the speed of rail service and bring about substantial unit cost reductions. The view that the railroads have been unable to invest sufficient capital funds in the postwar period to achieve the modernization that experience has proved feasible is widely held among rail managements and transport specialists, including many shipper representatives who desire an adequate supply of modern freight cars, improved service, and the relief from ever-rising freight rates in an inflationary economy that can be achieved only by the maximum cost reductions of which rail technology is capable. It is common knowledge among students of the railroads that capital for railway investment has been so short that many railroads can finance only the top high-return investments on their investment priority schedules. While highway investment also lagged during World War II and the rapid postwar expansion of motor-vehicle ownership and travel has created many highway bottlenecks, it is doubtful that the policy-makers, in deciding to raise the annual level of highway investment, made any specific comparisons to ascertain whether another billion dollars invested in transport could earn a higher rate of return (and thus yield greater economic benefits for society) in interstate highways on the one hand, or in interstate railways on the other. Manifestly, although highway traffic has been rising while rail traffic has been stable (freight) or falling (passenger), the institutional conditions of investment have been highly favorable to large-scale highway investments for improving motor transport service and lowering its costs, and have been equally unfavorable to higher levels of rail investment for exploring the cost and service gains that might also be achieved in that field. There is a very real possibility that the expanded public expenditures on highways may lead to overinvestment in that field and to underinvestment in the railroads. Even if the former possibility does not eventuate, however, the latter will deny society the full measure of transport progress unless policy changes more favorable to balanced investment in transport are adopted.

Government investment in the inland waterways and in airways and airports has also expanded materially in recent years. For example, the Corps of Engineers reported rivers and harbor expenditures for navigation in fiscal I953 of $\$ 183,400,000$ for capital construction and $\$ 88,800,000$ for maintenance, or a total of $\$ 272,200,000$ for all purposes. These levels compare with $\$ 28,300,000, \$ 60,900,000$, and $\$ 89,200,000$, respectively, in fiscal I947. And an additional $\$ 6,900,000,000$ of federal funds will be required to complete the federal program authorized for navigation (including multiple-purpose projects) through fiscal 1957. Federal appropriations for the riversand-harbors program amounted to $\$ 4,200,000,000$ through fiscal $x 954$, after adjusting

sa John W. Barriger, SUper-Raitroads for a DynaMic American Economy 7i (1956). 
for those portions of the cost of multiple-purpose projects that are assignable to nonnavigational purposes. Total federal airway expenditures have risen from $\$ 70,900,000$ in fiscal 1950 to $\$ 152,400,000$ in fiscal 1957 , of which those for cost of establishment rose from $\$ 17,500,000$ to $\$ 56,900,000$. Under a recent revision of the Federal Airway Plan, federal airway expenditures are scheduled to more than double between fiscal x 957 and fiscal $x 962$. Federal aid to airport construction, which ranged between $\$ 5,100,000$ and $\$ 33,200,000$ during fiscal years $1948-57$, was authorized to rise to $\$ 63,000,000$ a year in subsequent years under the I955 amendment of the Federal Airport Act. ${ }^{39}$ That level is more than double the average annual appropriations under the 1946 Act. ${ }^{40}$

Hence, under the political and economic pressures that insistently manifest themselves in the Congress, the investment programs for highways, inland waterways, and air facilities have been greatly increased in recent years. Unless such investment is tied more closely than in the past to the economic limits that would be imposed under complete user-fee financing and under economic criteria that would necessitate systematic consideration of the relative investment opportunities in all fields of transport, there will be no reversal of this trend in the future. In all likelihood, it will continue to be difficult, if not impossible, for the privately-owned railroads to expand their annual investment as much as technological opportunities warrant. Whatever these prospects mean in terms of improved air, motor, and water service and reduced carrier costs in those fields, they plainly endanger achieving, in addition, the maximum gains that appear possible from greater investment in the railroads. Indeed, they may well yield smaller benefits per dollar invested in transport facilities than might be obtained under a more balanced investment program for transport as a whole.

The recurrent car shortages, the highly disturbing commutation service discontinuances, and the vulnerability of important railroads to bankruptcy in time of modest recession all suggest that one effect of public expenditures on highways, air facilities, and waterways has been to discourage investment in the railroads. With low profitability prevailing for many years, the railroads cannot attract capital from the outside, except for equipment, and cannot greatly increase their investment from retained earnings. Since public investment and continuing subsidies in some transport fields have been factors in diversion of traffic and revenues from the railways, it must be concluded, too, that they have also contributed to limiting the investment levels in that industry. Low profitability in the rail industry, influenced in part by subsidies, discourages private investment; but political demands bring about more investment in the basic facilities for competing agencies, whether or not such investment is shown to be self-liquidating or must meet market tests of its worth.

\footnotetext{
${ }^{30} 69$ Stat. $44 \mathrm{I}, 49$ U.S.C. $\$ \S$ Iror-II (Supp. V, I958).

1060 Stat. I70, 49 U.S.C. $\S \S$ Iror-19 (1952). See NELson, op. cit. supra note I, at 85-88, 97-98, 100-03.
} 


\section{A Public Aids Policy for the Future}

The historic public policy of fostering transport innovations and development has been an important factor in stimulating the high productivity of the American economy by increasing the division of labor, the geographical specialization in industry, the volume of trade, and the economies in large-scale production. Along with private enterprise in the private sectors of transport, it has also contributed the most highlydeveloped, diverse, and efficient transport system in the world. By encouraging rapid use of new techniques of transport, it has greatly enriched social life and increased communication among people in a variety of ways.

It cannot be denied that initial subsidies to hasten the introduction of infant transport industries have contributed to early achievement of the important gains from improved transport. However, the original purposes for the historic subsidy programs have largely, if not completely, been accomplished, and in recent decades, the transport problem has substantially changed character. From stimulating an initial supply of efficient transport to develop the vast land resources of this country and from encouraging a more rapid introduction of a succession of new agencies than the market alone would have brought about, the national transport problem has changed to one of facilitating the right economic development of each mode of transport, including essential public way and terminal facilities. A solution to that problem must be found both to prevent an already tolerably adequate system from breaking down in essential areas and to minimize transport costs by eliminating wasteful investment and the costly practice of encouraging traffic to move over highcost rather than low-cost agencies.

As government, for good reasons, owns, manages, and finances airways, airports, highways, and inland waterways, there obviously remains a public need for continuing government investment in those facilities more or less indefinitely. While there is thus a permanent case for efficient public investment programs in transport and possibly one for public investment in rail roadway facilities to equalize the conditions of investment other than by adoption of universal user fees, no economic case can be made for a continuing program of subsidies in addition to the efficient public investment that the mixed system of transport makes necessary. As originally conceived, most subsidy programs for domestic transport had concrete national development objectives. These have largely or wholly been achieved. Present-day subsidies to domestic transport are designed for the special advantage of particular regions, industries, transport firms, and users, rather than for greater transport efficiency as a whole and for elevating the productivity of the entire economy to the maximum extent.

By relieving the carriers enjoying subsidies along with public facilities of some of the resource costs of producing their transport services, transport subsidies lower the cost of operation of such carriers. They thereby enable these carriers to quote lower rates than otherwise would be the case Since their rates do not include all 
economic costs, it is often impossible for shippers and travelers to select the agency and carriers economically best fitted to render the service demanded. The inevitable result is that traffic tends to be diverted from agencies and carriers having lower resource costs than the subsidized carriers. In turn, this means that traffic tends to be induced to flow over high-cost rather than low-cost agencies. Although other factors have also influenced much diversion from the railroads in recent years, there can be no doubt that a part of that traffic diversion has been uneconomic. ${ }^{41}$

Moreover, since traffic and revenue diversion from the railroads has been increased by subsidies to competing modes, it follows that continuing subsidies have been a factor in the railroads' deteriorating postwar condition. The tax and cost-of-capital advantages to carriers using public ways and terminals have further contributed to low rail earnings and to underinvestment in rail plant. Finally, the far greater availability of capital funds for airway, airport, highway, and waterway expansion and modernization, the result of powerful political pressures for public investment, as well as the induced expanding traffic volumes carried by those facilities, has tipped the scales further in favor of rapid technological advances in air, motor, and water transport. Meanwhile, modernization lags in the rail industry, and equipment and motive power are often inadequate to handle present traffic. Clearly, if nothing is done to eliminate unnecessary subsidies and to encourage a greater flow of capital into that industry as well as into competing agencies, the country will be taking grave risks of losing essential and self-sustaining rail services and plant that even now are needed to transport the traffic load efficiently and may again be more urgently required when traffic is at wartime peaks. It, therefore, seems foolhardy for the nation to ignore this situation when the evidence logically points to subsidies and unbalanced transport investment as factors in the disturbing condition of the railroads. The means are at hand for correction of those deleterious influences in behalf of the public welfare as a whole.

The first step that should be taken is to enact a policy of user fees for all agencies using public way and terminal facilities. As the chief gaps in user fees are the lack of explicit charges for use of the civil airways and the inland waterways, only federal action is required. The Civil Aeronautics Administration has made several studies of user charges for the airways and has found them feasible. ${ }^{42}$ Programs of airway user fees have been recommended to the Congress by President Eisenhower, and in 1957, the Department of Commerce was directed to study the feasibility of tolls for use of waterway channels and locks. ${ }^{43}$ As the Department of Commerce report should be issued in the near future, there should be no significant technical difficulties

«Id. ch. Io.

19 CAA, U.S. Dep't of Commerce, A Program of Charges for the Use of the Federal Airways System I21-3I (I953); id. at 6-7 (Supp. No. T, 1954). Cf. Meyer, Peck, Stenason, \& Zwick, op. cit. supra note 1 , at $139-44$.

13 See the Budget Message of the President, in The Budget of the United States, Fiscal Year I959, at M30-3I (I958); id., Fiscal YeAR I960, at M47-50 (1959); the Bureau of THE BudGet, BuLl. No. 58-3, User Charges for Certain Government Services (I957); Dep't of Commerce Release No. G-850, Nov. 27, I957. Cf. Meyer, PeCK, Stenason, \& Zwick, op. cit. supra note I, at I22-26, 148. 
in the way of prompt legislation to enact user fees for the airways and waterways. On the other hand, such proposals will encounter stout political opposition from the transport industries involved and from communities that differentially benefit from subsidies. Eventually, however, national concern over the prospect of inadequate rail transport, the need for greater economy in transport as a whole, and the pressure of other claimants for general federal funds will offset the opposition of the pressure groups benefiting from subsidized transport.

After the gaps in the user-fee picture have been closed, the next logical step will be to adjust existing user-fee systems more in accordance with economic pricing of public way and terminal facilities as rapidly as that may be possible. Such an effort will involve the states as well as the federal government; and because of the unsettled state of knowledge concerning the behavior of highway costs, some real difficulties will be encountered. ${ }^{44}$

The adoption of federal highway user fees for the first time in 1956 represented significant progress. However, refinement of the predominant state pattern of highway user fees (uniform fuel taxes and graduated registration fees without mileage components) adopted at that time to pay for federal-aid highways was left until January 3, г96I. By that date, the Bureau of Public Roads must complete a comprehensive series of studies designed to ascertain how highway costs are affected by the size and weight of motor vehicles as well as by their mileages of use. The Bureau will also report to the Congress on other factors that might be taken into consideration in adjusting the federal highway user fees in terms of economy and equity. ${ }^{45}$ If the Congress eventually improves the present federal user-fee structure by adopting a diesel differential in the fuels tax and in other ways that the evidence may support, it can be expected that the states would rapidly accept the federal leadership and adjust their highway user fees accordingly. Though a distinct opportunity was missed in $195^{6}$ to make some much-needed improvements in the highway user-fee structure, it is far from too late to remedy the situation. A few states have long ago attacked some of the outstanding structural defects of highway user-fee schedules by adopting diesel fuel tax differentials and weight-mile schedules, and in many states, voluminous research has been done on highway pricing. Although the earlier Maryland and Idaho test roads were disappointing because they were not designed to throw specific light on the additional highway service costs caused by the large and heavy vehicles, the current ASSHO road test in Illinois should shed much light on that critical question. In the case of user fees for airways and waterways, effort should be made to adopt economic schedules in the beginning, allowing them to take effect gradually over a period of years if desirable to lighten the burden of adjust-

\footnotetext{
"See Robert F. Baker, Robert Chieruzzi, \& Richard W. Bletzacker, Highway Costs and Their Relıtionship to Vehicle Size (The Ohio State University, Engineering Experiment Station Bull. No. I68, I958).

${ }^{\circ 5}$ Tallamy, supra note 2I, at I-6. See also Kafoglis, Price Theory and Tax Equity in Highway Finance, paper delivered before the Annual Meeting of the Highway Research Board, Jan. I959, pp. 2-12.
} 
ment by the carriers to having to pay fully for government-provided way and terminal services.

Finally, a number of other policies require modification, and the railroads must do far more in their own behalf by engaging in effective competitive pricing on the basis of their own unit costs by making rapid service innovations, by dealing vigorously with their labor problems, and by directing their investments into channels that will bring the greatest returns. ${ }^{46}$ Although the subject is beyond the scope of this article, there is also an urgent need to modify the current transport regulatory policies to permit all agencies to make their inherent advantages of cost and service effective in the market place and to lessen the drags and costs of excessive regulation of an essentially competitive transport system. Without this, the railroads cannot effectively solve their outstanding problems; nor can the present uneconomic market stimuli to overexpansion of certain fields of transport be avoided.

There is an urgent need, too, for more coordination in government planning with respect to the investment schedules for public transport facilities. First, a Department of Transportation is essential in order to provide facilities for supervision and checking of all investment needs estimates and for comprehensive and continuous research into the economic effects of federal transport policy. ${ }^{47}$ Second, uniform economic criteria should be developed for justifying specific projects in any field of public transport, including consideration of the social costs of federal financing, tax effects, and the investment opportunities in privately-owned areas of transport as well as the several fields of publicly-owned transport. Much useful work has been done in recent years, both within the federal government and by academic economists, on the investment criteria problem, including some critical evaluations of the errors and exaggerations involved in the economic justifications prepared by various federal agencies. ${ }^{48}$

In conclusion, entirely too much of the nation's capital is involved in public transport investments and too much is at stake in terms of the future of the privately-owned railroads to make it sensible to continue the past separate consideration of the investment needs in each area of public transport. The techniques and much of the knowledge required for developing economic and coordinated public transport investment programs are at hand. In addition, it should be recognized that no public need now exists for continuing subsidies to domestic transport via failure to consider all resource costs in expanding public transport facilities or failure to charge user fees for all agencies using such facilities.

${ }^{10}$ Nersos, op. cit. supra note $\mathrm{X}$, at 419-27 and chs. 8-1x.

${ }^{27}$ See Mackie, The Necessity for a Federal Department of Transportation, 8 J. Pü. L. I (1959).

${ }^{28}$ See, e.g., Otro Eckstein, Water Resource Development ch. VI (1958); Edward F. Rensiaw, Toward Responsible Government ch. V (1957); Cecil B. Haver \& Edward F. Renshaw, The Future OF THE ILLINOIS WATERWAY I-3 (1957). 